\title{
Exploring human responses to climatic fluctuations and environmental diversity: Two stories from Mesolithic Norway
}

\begin{abstract}
This paper explores environmental variations in time and space, adaptive strategies and possible cultural responses to climatic changes as manifested through archaeological data in terms of lithic tool technology, site density and settlement patterns. The objective is investigated by two case studies from Mesolithic Norway. The first case deals with the earliest settlement phase of Norway (c. 11,500-10,000 cal. BP), which climatically encompasses gradual changes from cold, arctic conditions, to a milder sub-arctic climate, as well as the rapid Preboreal Oscillation (PBO) cold event. The second case explores the 8200 cal. BP cold event and its effect on culture and settlement in Southeast Norway.
\end{abstract}

The studies suggest that the coastal settlement, in terms of site density, was not affected by either the PBO or the 8200 cal. BP event. Changes in site location patterns seem to have occurred gradually and on a long-term scale. Shifts in lithic technology are detected within the Mesolithic periods, but a correlation between abrupt climatic alterations and cultural changes are yet to be proved. We argue, therefore, that in these northern, coastal environments, declining temperatures may have had less impact than on the Continental Plains, and may in fact have improved the living conditions for a range of marine species. Also, the Mesolithic populations seemed to have employed a generalized lithic toolkit and a flexible mobility system - adaptive strategies that was able to withstand environmental variantions in time and space.

Keywords: Marine foragers; coastal settlement; adaptive strategies; shoreline displacement; Preboreal Oscillation; 8200 cal. BP event 


\subsection{Introduction}

Scandinavia and Norway underwent severe topographic, environmental and climatic changes during the Lateglacial, early and mid Holocene periods (c. 12,000-6000 cal. BP). Palaeoenvironmental data bear witness to fluctuations in temperatures, sea levels, and terrestrial and oceanic ice-cover, as well as changes in vegetation, faunal composition and marine conditions following the glacial meltdown. How did the human groups that populated the Norwegian landmass during this period cope with the massive changes? In the course of a several thousand year time span of environmental change, we do, as in other regions, find shifts in demography, settlement patterns and lithic tool technology (e.g. Birks et al. 2015; Hoek et al. 2015; Jessen et al., 2015; Crombé and Robinson, 2016; Damlien, 2016a; Perez et al., 2016). But are these cultural and natural trajectories synchronous and directly related? And which adaptive strategies were employed in order to approach and utilize the temporally and spatially varied Norwegian landscape?

In this article we explore these questions by combining archaeological and palaeoenvironmental data from Mesolithic Norway. We present two case studies that investigate possible links between variations in environment, lithic tool technology and settlement patterns.

The first case deals with relations between humans and environment in the earliest settlement phase of Norway, the Early Mesolithic period (c. 11,500-10,000 cal. BP), with particular emphasis on marine conditions in Central Norway. The period embraces the gradual changes from cold, arctic conditions, to a milder sub-arctic climate, as well as the rapid Preboreal Oscillation cold event at c. 11,300-11,200 cal. BP. Archaeologically, the Early Mesolithic of Central Norway is characterized by small settlements made up of deposits of lithic tool implements and debris, and occasionally hearths and/or tentrings. Organic material is normally not preserved from this period. Most of the known settlements are situated in the outer coastal zone, but a small portion is found in mountain and inner fjord environs (Svendsen, 2007; Bjerck, 2008; Nyland, 2012a; Breivik and Callanan, 2016).

The second case is a work in progress, and will explore the 8200 cal. BP cold event and its 
effect on material culture and settlement in Southeast Norway. The geological background of the region, along with the extensive archaeological data, makes it well suited for studying temporal variations in coastal settlement and lithic technology in relation to paleoenvironmental records. The majority of Mesolithic sites in Southeast Norway are characterized by concentrations of lithic material and features like hearths and cooking pits. Occasionally, remains of pit houses or huts are documented. Organic material is badly preserved except for burnt/cremated bones and hazelnut shells. Most sites are located along former shorelines around the Oslo fjord, but sites are also abundant along the main watercourses stretching inland, and in the mountain region.

Norway has the advantage of having undergone a severe isostatic land uplift during Lateglacial/Post-glacial times, meaning that even the earliest coastal sites are situated above present sea level. This gives us the opportunity to gain holistic views of the archaeological sites and artefacts through time and space. Moreover, as the speed and nature of this process is quite well documented, we are able to determine the approximate oldest possible age of archaeological sites by measuring the present elevation above sea level - provided that the site in question was situated close to the contemporary shoreline (see Case study 2 for thorough discussion about this). Thus, the archaeological record of Norway is suited to illuminate the relation between Mesolithic marine foragers and their fluctuating surroundings (Bjerck, 2009).

\subsection{Case study 1: Relations between humans and environment in}

\section{Early Mesolithic Norway (c. 11,500-10,000 cal. BP)}

\subsection{Background}

The Pleistocene-Holocene transition is described as a severe and abrupt climatic event (e.g. Burroughs 2005, pp. 43-47). On the Continent, temperatures rose rapidly, the ice sheet diminished, tundra turned into grasslands and then forests. On the Scandinavian Peninsula, the ice lingered long into the early Holocene (Stroeven et al., 2015), and the environment was still influenced by cool temperatures in the first few centuries of this period. 
Palaeo-oceanographic data suggest that inner fjord areas, sheltered waterways and other sea areas that experienced great meltwater influx, had severe ice-cover or were seasonally frozen in the transition phase (Breivik, 2014). A cold tolerant marine fauna, probably consisting of a range of whales, seals, fish and birds, frequented the coastal waters, and terrestrial animals like reindeer and arctic fox thrived on land (Fredén, 1975; Jonsson, 1995; Hufthammer, 2001; Aaris-Sørensen, 2009; Grøndahl et al., 2010). It was under these conditions that the Norwegian land was colonized, and for 1500 years (c. 11,500-10,000 cal. BP) hunter-gatherers occupied and utilized the landscapes and resources provided by the emerging land and sea.

Two points concerning human-environment relations in this region and chronozone are of particular interest:

- The archaeological site distribution pattern suggests a cultural affinity towards the coastal zone and marine resources. It is therefore essential to bring the palaeooceanographic development into discussion when studying climatic fluctuations and cultural variations in this context: How did the climatic changes affect the marine environment and resource situation? And how does archaeological data relate to this trajectory?

- The inland sites, which are few in number but nevertheless present, means that the colonizers encountered, explored and utilized a diverse range of landscapes and resources. Are the topographical variations reflected in different lithic tool assemblages and settlement structures across ecozones?

This was the starting point of Breivik's PhD thesis (Breivik, 2016), of which the purpose was to investigate dynamic relations between humans and environment in the earliest settlement phase of Norway. In this article, the main results from this work will be presented.

\subsection{Regional setting: Central Norway}

Central Norway (Figure 1) is located between $62^{\circ} \mathrm{N}$ and $65^{\circ} \mathrm{N}$. The topography ranges from skerries, islets, and islands, through sheltered sounds and narrow fjords, to mountain plateaux and subalpine landscapes. The geographical area is well documented by systematic mappings of sites during the last 100 years (see Breivik and Ellingsen, 2014), and several 
detailed studies of the artefact assemblages (Bjerck, 1983; Møllenhus, 1977; Svendsen, 2007). The sites are distributed at different elevations, and age determinations based on shore-displacement diagrams suggest that the archaeological record covers the whole Early Mesolithic timespan. A recent synthesis charts around 300 Early Mesolithic sites in Central Norway (Breivik and Bjerck, in press), and the region thus seems to have the densest concentration of settlements in the country (see Table 1 and Figure 2). Early Mesolithic sites have been preserved and investigated in both the coastal and mountain zones, and the relatively short distances between mountain and coastal sites in the region, connected as they are by fjords cutting deep into the interior, mean that they are likely to have formed part of the same mobility system in the past. The Early Mesolithic archaeological record of Central Norway is thus well suited to explore temporal and spatial human-environment dynamics.

Figure 1: Map with regions and placenames mentioned in the text. Illustration: Jonas J. Håland.

\subsection{Material and methods}

In order to answer the research questions, archaeological and palaeoenvironmental data from the period was collected and compiled. First, the environmental and climatic trajectory in the Early Holocene period, with focus on coastal and marine conditions, was mapped. As the palaeoenvironmental data presently do not allow for a detailed reconstruction of the faunal composition, emphasis was put on characterizing variations in marine productivity through space and time. This was done by way of collecting and compiling analyzed and published palaeo-oceanographic data and assessing how topography, bathymetry, oceanic current systems, sea-ice and melting glaciers would have affected marine productivity (in the form of phytoplankton production). The published palaeo-oceanographic data mainly consist of sediment cores that are collected from the Norwegian Sea, the North Sea and the Barents Sea. The temporal and spatial resolution is quite coarse, and it was only possible to characterize the over-regional development through relatively long time sequences.

In Breivik's PhD project it was aimed at making a complete database of Early Mesolithic sites in Norway. Due to the lack of preserved organic material, we have to rely on a combination of typology and shore-displacement diagrams when dating the sites. This work was 
approached by searching published and unpublished literature for sites with diagnostic Early Mesolithic artefacts (see below; Breivik, 2014). A more thorough search was conducted for Central Norway. This involved an extensive search for typological objects in the National Artefact Database and digitalized Collection Catalogues, including a subsequent examination of the assemblages with the purpose of confirming or invalidating an Early Mesolithic date. The artefact assemblages from this chronozone are characterized by a number of distinct types and technological traits, and includes flake-adzes, core-adzes (Lerberg and similar), small tanged points (single-edged and oblique-edged), microliths (lancets and rhombic lancets), micro burins and unifacial cores with opposed platforms and acute striking angle (e.g. Mikkelsen, 1975; Bjerck, 1983; Olsen, 1992; Kutschera and Waraas, 2000; Waraas, 2001; Fuglestvedt, 2005, 2007; Bjerck et al., 2008).

All sites that included one or more such diagnostic artefacts, and that additionally were dated by shore-displacement curves and/or radiocarbon dating, were counted as "certain" Early Mesolithic sites. Sites that did not include typological markers, but were dated by shoreline displacement curves and contained raw materials and/or technological traits associated with the Early Mesolithic period, were counted as "uncertain" sites. All sites were georeferenced as precisely as the data allowed in order to visualize the spatial distribution of sites.

A potential of 771 Early Mesolithic sites were mapped nationally (see Table 1 and Figure 2).

Table 1: Number of identified and mapped Early Mesolithic sites in Norway. The sites are dated by a combination of typology and shoreline displacement curves, and in a few cases radiocarbon dates. "Certain" sites denote sites that contain one or more diagnostic artefacts, and that additionally were dated by shore-displacement curves and/or radiocarbon dating. "Uncertain" sites that did not include typological markers, but were dated by shoreline displacement curves and contained raw materials and/or technological traits associated with the Early Mesolithic period.

Figure 2: Map showing the distribution of Early Mesolithic sites in Norway. "Certain" sites (sites containing diagnostic artefact(s) and/or radiocarbon dates) are marked with black dots; "uncertain" sites (sites without diagnostic artefacts but dated by shore-displacement curves/raw material/technological traits) are marked with grey triangles (Breivik, 2016, Fig. 4).

Archaeologically, three factors were chosen to investigate adaptive behavior in relation to environmental and climatic fluctuations occurring in the Early Mesolithic period: lithic toolkit, settlement patterns and site density. Based on other case studies from Northern Europe (e.g., Crombé et al., 2011; Riede, 2009; Tallavaara and Seppä, 2011) these cultural aspects are likely to change according to altered resource situations. For the purpose of the analyses, 86 sites from Central Norway that contained typological markers, and had 
sufficient mapping information to be dated within time slices of 100 years BP by sea-level curves, were selected. In this present article, the analyses of temporal changes in lithic toolkit and settlement pattern is extended by including a total of 131 sites that can be age determined within either the early or late Preboreal period (see below). This gives us a larger material to conclude from.

\subsection{Results and discussion}

\subsubsection{Temporal variations in environment and culture}

The review of palaeo-environmental data showed that Norway underwent quite severe changes in the course of the 1500 years Preboreal/Early Mesolithic pioneer phase; from a cold arctic to a milder sub-arctic climate (e.g., Birks et al., 2005; Risebrobakken et al., 2010). Based on this trajectory, the Preboreal was subdivided into an early (c. 11,500-10,800 cal. BP) and a late (c. 10,800-10,000 cal. BP) phase. In the early Preboreal phase many of the large fjords were still glaciated and/or were transporters of meltwater from the diminishing ice sheet. This probably caused seasonal freezing scenarios in adjacent waters, as water from glacial input zones enhances stratification, which in turn enhances sea ice formation (Statham et al., 2008). In northernmost Norway (Finnmark County), more severe freezing is recorded, as the ice-cover in the southwest Barents Sea extended further south than today (Risebrobakken et al., 2010). From the climatic and environmental reconstructions, we can gather that the cold tolerant fauna was still frequenting the Norwegian coast in this phase. Ice-obligate species (polar bears, walruses, bearded seals, and ringed seals; see Moore and Huntington, 2008) would thrive in the frozen waters during the coldest months. An almost complete skeleton of a bearded seal from the Trondheimsfjord in Central Norway has recently been dated to c. 10,300 cal. BP (Rosvold and Breivik, in press). In northernmost Norway arctic sea mammals may have found suitable habitats throughout the year.

An abrupt cold event, referred to as the Preboreal Oscillation (PBO), is documented in north Europe at 11,300-11,200 cal. BP (Björck et al., 1997). The PBO had widespread ecological consequences that must have been noticeable to humans occupying Norwegian landscapes: air and sea temperatures plummeted, vegetation diminished, and terrestrial ice sheets readvanced. It may also have caused longer lasting seasonal ice covers in sheltered waters and fjords. 
At 10,800 cal. BP, the glaciers had retreated from the fjords, the Norwegian Atlantic current became established along the coast (Birks et al. 2005), and the oceanic regime thus became more like the present, meaning less meltwater influx and more input of warm and salty water masses. In the northernmost region, however, cold conditions lingered. With the environmental shift, ice-obligate marine mammals would have been pushed northward as the temperatures increased and the ice dissolved. A more temperate fauna with new fish species would find their way into Norwegian waters, and a more diverse avian fauna is expected. The late Preboreal phase can thus be characterized by increased stability in the marine conditions - consequently with more constant habitats for fish and sea mammals and hence a more predictable resource situation for human predators (Breivik, 2014).

The first cultural factor studied was changes in site density, where it was expected to see a declining trend following the PBO cold event. This assumption was based on similar studies (e.g. Tallavaara and Seppä 2011) where climatic deteriorations resulted in reduced or changed resource distribution, and subsequently a decrease in human populations. The 86 sites form Central Norway that had sufficient mapping information to be dated within time slices of 100 years BP did show fluctuations in site density through the period (Figure 3). It did not, however, support the hypothesis related to the PBO. On this basis, it was suggested that the cold event did not have a severe negative effect on the resource base (Breivik, 2014). During the last decades of archaeological research there has been increased focus on the coast as an attractive environment for human foragers. The oceans are now highlighted as rich ecosystems - especially in high-latitudes (Huston and Wolverton, 2009). Recognizing polar marine environments as highly productive would propose that the coastal zone provided ample resources also during climatic cold events.

Figure 3: Changes in site density through the Early Mesolithic period. The diagram shows no direct relations between the Preboreal Oscillation (PBO) cold event and a decline in site numbers. The calculations are based on 86 sea-level dated sites from central Norway (Breivik, 2014, Fig.4).

The second factor studied was possible correlations between the environmental shift from early to late Preboreal and changes in lithic toolkit. Changes in the natural preconditions may have initiated changes in subsistence or hunting strategies, visible as declining trends in 
the representation of some of the large artefact categories, as demonstrated by e.g. Riede, 2009 and Crombé et al., 2011 in northern Europe. In southern Norway, a decline in the use of tanged points for the benefit of microliths during the Early Mesolithic has been recorded (Fuglestvedt, 1999; Kutschera, 1999; Waraas, 2001). Similar trends are documented in South Scandinavia (e.g. Kindgren, 1996). When studying the Early Mesolithic artifact assemblages of the 86 selected sites of Central Norway, however, we found no severe decrease in the selected tool types through the period - most of the categories showed upwardly trends (Breivik, 2014). The present extended analysis of 131 sites that contained typological markers and could be sea-level dated within the early (11,500-10,800 cal. BP) or late (10,800-10,000 cal. BP) Preboreal, show an upwardly trend in the share of sites containing flake adzes. Core adzes retain the same significance throughout the period, as do microliths. Tanged points do actually show a declining trend, but appear just as frequently as microliths in the late Preboreal phase (Figure 4). This speaks for a lithic toolkit that was more or less maintained despite the environmental changes, and a shift in projectile preference is not recorded in Central Norway.

Figure 4: The percentage of analyzed sites containing flake adzes, core adzes, microliths and tanged pointsin the first and second half of the Early Mesolithic period. The diagram shows that the tool inventory remained more or less unchanged throughout the period. The calculations are based on 131 sea-level-dated sites from Central Norway.

Finally, relations between settlement patterns and the gradual stabilization of marine conditions were investigated. The changed resource situation that occurred as the Norwegian Atlantic current established along the coast, ice withdrew from the fjords and sea surface temperatures increased around the mid Preboreal (c. 10,800 cal. BP) may have made new locations preferable to the Early Mesolithic foragers. The distribution of the 86 archaeological sites from the same region did indeed speak for a shift in settlement location strategy during this time span; from almost exclusively inhabiting the islands of the outer archipelago in the first half of the period, there was a propensity towards the use of more retracted locations (fjord basins or sheltered sounds connected to the mainland) in the second half of the period (Breivik, 2014). The present extended analysis of 131 sites supports this pattern (Figure 5).

Figure 5: The percentage of analyzed sites with retracted (in fjord basins or sheltered sounds, oriented towards the mainland) and exposed (in the outer archipelago, oriented towards the open sea) location in the Early and Late Preboreal 
phases. The calculations are based on 131 sea-level dated sites from Central Norway. The diagram shows that there are an increasing number of sites with retracted location in the second phase.

\subsubsection{Adaptive strategies in a spatial perspective}

According to the national Early Mesolithic distribution map presented in Figure 2 some $96 \%$ of the archaeological sites were situated in the coastal zone and $4 \%$ in the mountain zone. The distribution analysis also showed that most of the settlements of Central Norway were situated in the outer archipelago, the zone where the marine primary production would be highest, suggesting a tight relation between resource abundance and choice of camp location and stressing the great dependence on marine resources (Breivik, 2014). Nevertheless, Early Mesolithic hunter-gatherer groups also exploited mountain environments - a landscape and resource situation completely different from the coastal zone. The mountain zone was influenced by the retreating glacier during the Early Mesolithic. Large parts of the mountain plateau was deglaciated before valleys and fjord heads, and hosted good pastures for terrestrial animals such as reindeer, foxes and hares at an early stage. How did colonizing populations meet the challenges posed by these different ecozones?

In Breivik's PhD project, twelve sites and artefact assemblages from the outer archipelagic zone and the mountain zone in Central Norway were compared for the purpose of detecting ecozone-specific adaptations and specializations as manifested through site organization (site size, size and number of lithic concentrations, number of artifacts, number of occupations, traces of fireplaces and dwellings), lithic artefact composition (formal and informal tools, blades, cores, flakes and tool production debris), projectile morphology (metrics and types) and raw material use (raw material composistion and cortex blades) (Breivik, 2016; Breivik and Callanan, 2016).

The analysis first and foremost underlined a number of structural similarities in how sites were organized and used in mountain and coastal landscapes. The settlements were organized equally in terms of size, structure and features: they appear as lithic scatters measuring between 6 and $45 \mathrm{~m}^{2}$; occupation areas usually contain a denser concentration of lithics that range between c. 2 and $12 \mathrm{~m}^{2}$; and remains of dwelling features and fireplaces 
are found in both zones. Moreover, the lithic inventories seemed to share a fundamental structure, reflecting all the steps of lithic tool production; from primary reduction of flint nodules, through production, maintenance, and use, to discard of artefacts. Also, upon studying the single most common tool category within the selected assemblages, projectile points, it was observed that the size and shapes were similar across the ecozones (Figure 6a and b).

Figure $6 a$ and $b$ :

a) Early Mesolithic flint projectiles found on coastal sites in central Norway. A-C: Ormen Lange Site 48 Unit G; D-F: Ormen Lange Site 48 Unit A; G-I: Ormen Lange Site 72 Unit X; J: Ormen Lange Site 48 Unit I; K: Ormen Lange Site 48 Unit J; L: Hestvikholmane 3; M \& N: Hestvikholmane 2-2012; O \& P: Kvernberget Site 20; Q \& R: Ormen Lange Site 72 Unit Y. b) Early Mesolithic flint projectiles found on mountain sites in central Norway. A-H: Reinsvatnet R1; I-L: Sandgrovbotnen; M-R: Brannhaugen. Photograph by permission of NTNU University Museum/Åge Hojem (Breivik and Callanan, 2016, Fig. 6 and 7).

Some ecozone-specific variations in the artefact inventories were, however, found: The mountain sites had a generally lower percentage of flakes and debris, larger amounts of blades and cores, and a relatively high percentage of tools (Figure 7). The high percentage of tools on mountain sites supports the idea that they were camps where gearing-up and tool maintenance sessions connected to hunting events were undertaken (Callanan, 2007). Moreover, projectiles and scrapers played a more important part in mountain inventories compared to the coastal assemblages. There also appeared to be a higher dependency on informal tools in the mountains. This probably reflects the particular situation where the Early Mesolithic groups relied heavily on flint - a raw material that only could be found as pebbles in beach deposits. The relatively small proportions of cortex blades (blades where at least 50 per cent of the outer cortex usually found on natural flint nodules is still present) recovered from the mountain sites underlines that flint nodules were prepared before they were brought inland. Based on the lithic artefact composition, it was argued that the assemblages from the coastal sites generally spoke for a wide range of more or less fixed activities (see Bjerck et al., 2008: 558, 565), while the three mountain assemblages appeared to reflect a narrower set of activities. Yet, the lithic package found on mountain sites were made of elements that originated from the broader repertoire seen on the coast, and the basic form and size of the technical pieces in question were the same. It was concluded, therefore, that the Early Mesolithic colonizers employed a generalized lithic technology that included tools suitable for a wide range of tasks (Breivik and Callanan, 2016). 
Figure 7: Comparative overview of the composition of the Early Mesolithic inventories found on 12 coastal and mountain sites in central Norway. The values presented are percentages of the total inventory. The diagram shows that the mountain sites have a lower percentage of debris and a higher percentage of tools than the coastal sites (Breivik, 2016, Fig. 11).

\subsection{Conclusion}

The studies suggest that the Early Mesolithic forager groups of Norway had resilient adaptive strategies that were able to withstand fluctuations and variations in landscape, climate, environment and resource bases. By employing a generalized and expedient lithic tool technology, they could make instruments that were ready to be pressed into different tasks. Although focusing on marine environments, their subsistence strategies encompassed different habitats and resources, including visits to mountain environs. The site structure and tool assemblages that were used on the coast were projected into this context, with small adjustments governed by the different activities and raw material situation associated with the two landscapes. This generalized adaptive strategy had its roots in the Palaeolithic cultures of the continental plains. In the Pleistocene-Holocene transition, the groups expanded into archipelagic seascapes. In so doing, their technology must have included sturdy sea-going vessels. The fact that their lithic toolkits and settlement organization was maintained throughout the 1500 years long Early Mesolithic phase, speaks for an adaptation strategy that was designed for a multifaceted environment. Their technology were already well tested in harsh Lateglacial environments on the continent, where changing and unstable natural surroundings was the rule rather than the exception. In addition, seasonal fluctuations in weather conditions and resource base may have been just as marked as the gradually changing climate or the differences between ecozones. Perhaps more vital than altering their material culture and social structures according to changing surroundings was the possession of knowledge about the landscapes in which they moved. Learning about animal behavior, seasonal changes, risks and opportunities connected to different habitats and ecozones may have been the key to successfully colonizing and seeking out resources in the varied Norwegian landscape as it emerged from the ice. 


\subsection{Case study 2: The $8200 \mathrm{cal}$. BP cold event in the Oslo fjord region.}

\subsection{Background}

The use of paleoenvironmental data in Mesolithic (c. 11,500-6000 cal. BP) and Neolithic (c. 6000-3800 cal. BP) research has a long tradition in Southeast Norway, first and foremost in studies of shoreline displacement trajectories (Anundsen 1985; Hafsten 1983;

Henningsmoen 1979; Svendsen, et al. 2004; Svendsen and Mangerud 1987; Sørensen 1979; Sørensen, et al. 2014), and early farming by pollen analysis. Quite a substantial amount of pollen sediment cores from bogs and lakes have been analyzed as part of archaeological projects (e.g., Høeg 2005) and significant work for reconstructing the development of the Holocene landscape and vegetation history has been carried out in relation to large-scale excavation projects (e.g., Sørensen et al., 2014; Wieckowska-Lüth et al., 2015, in prep.).

A challenge for detailed analyses of human-environment dynamics, and more specifically the 8200 cal. BP event, is the lack of fine resolution of pollen analyses or that the pollen record do not cover the period of interest. The 8200 cal. BP cold event coincides with changes in the archaeological assemblages with the transition from the Middle Mesolithic to the Late Mesolithic Nøstvet/Lihult complex (Glørstad, 2004). The relation between the 8200 cal. BP event and cultural change is however little explored in the region, and the integration of high-resolution paleoenvironmental data with archaeological datasets has only been performed to a minor extent, particularly concerning human response to rapid climate change. The lack of available high-resolution environmental data is one obvious explanation. During the last decade there has been a regaining interest in human-environment interactions in archaeological research, and topics such as foraging, subsistence, human adaptions, ecology, and demography are again becoming highly relevant (e.g., Breivik, 2014; Manninen, 2014; Solheim and Persson, 2016). Here we will look into the potential for studying the climate event and its effect on culture and settlement in Southeast Norway. We aim to investigate how and if the 8200 cal. BP event affected lithic technology and temporal trends in settlement in the region.

\subsection{Regional setting: Southeast Norway and the Oslo fjord region} The Oslo fjord region is situated in the eastern part of Norway, and is located between $58^{\circ}$ 
and $62^{\circ} \mathrm{N}$ and covers a total of $94575 \mathrm{~km}^{2}$ (see Figure 1). The topography ranges from skerries, islands, fjords, large valleys/river systems, flat, agricultural land to alpine landscapes. The geographical variation is considerable and includes five vegetation zones: The hemiboreal zone is located along the coast of the Oslo fjord, the south boreal zone in the inner coastal areas and the finally the inland comprises the middle boreal zone, the north boreal zone and the alpine zone (Moen, 1999). Southeast Norway is sheltered from the large weather systems coming in from the Atlantic Ocean by a mountain range stretching north-south in large parts of Southern Norway. The region has low annual precipitation, warm summers and cold winters. Due to the large geographical variation, different vegetation zones and biotopes are accessible within relatively short distances. This allows human exploitation of a variety of resources, and this may have been a great advantage for hunter-gatherers in Southeast Norway.

\subsection{Data and preliminary results}

\subsubsection{Shoreline displacement}

There has been continuous land uplift in Southeast Norway after the retreat of the Scandinavian Ice Sheet, c. 12,500 cal. BP, and the glacio-isostatic rebound has caused dramatic changes in the region's landscape due to heavy land uplift (Bergström, 1999; Sørensen et al., 2014). This is most noticeable in the early part of the Holocene where a land uplift of c. $9 \mathrm{~m} / 100$ years is documented in the western part of the region (Sørensen et al., 2014). The isostatic rebound quickly stabilised at c. $1 \mathrm{~m} / 100$ year at the Boreal transition and during the Atlantic period the land uplift and thus changes in the landscape was declining, due to a combination of the glacio-isostatic rebound and the Mid-Holocene transgressions documented elsewhere in Scandinavia (e.g., Bondevik et al., 1998; Påsse, 2003).

Studies of the shoreline displacement are well integrated in the archaeology of Southeast Norway, and mapping of prehistoric shorelines are crucial for the Stone Age archaeology of the region, as it serves as the most common and available dating method. The mapping of the shorelines and construction of shoreline curves are done in close cooperation between archaeologists and geoscientists, but the shoreline displacement curves are created independently of archaeological data (e.g. Sørensen et al., 2014). The shoreline curves are also of importance for understanding the settlement in the prehistoric coastal landscapes 
and exploitation of marine resources (Jaksland, 2014; Glørstad, 2016). The geological background of the region underlines the potential in studying temporal variation in coastal settlement in Southeast Norway, as it is possible to document coastal settlement on dry land from the entire Holocene. Coastal sites dating from the colonisation period to the Neolithic transition, 11,500-5900 cal. BP, is easily accessible and well preserved.

\subsubsection{The $8200 \mathrm{cal}$. BP event in the Oslo fjord region - palaeoenvironmental data} The 8200 cal. BP event is detected in palaeoclimatic records in the North Atlantic region (Alley et al., 1997; Barber et al., 1999; Alley \& Ágústdóttir, 2005; Seppä et al., 2007, 2009; Walker et al., 2012), and is also evident in terrestrial climate records from Southern Norway. Proxy data from the south Norwegian mountains indicates a drop in summer temperature, re-advancing glaciers (the Finse event) and a pine pollen decline (Dahl and Nesje, 1994, 1996; Paus, 2010). Pollen records from Bohuslän and Southern Sweden, also demonstrate a drop in temperatures around 8200 cal. BP (Hammarlund et al., 2003; Antonsson and Seppä, 2007). Using chironomids subfossil assemblages from six low-alpine and sub-alpine lakes as temperature indicators, Velle et al. (2005) has obtained a regional picture of Holocene summer temperature change in Southern Norway and Southern Sweden, and the 8200 cal. BP event is detected as a fall in summer temperatures. Furthermore, marine paleoenvironmental records from Skagerrak show an interval of cooling and a decrease in salinity corresponding in time to the 8200 cal. BP event (Erbs-Hansen et al., 2011). Rohling and Pälike (2005) argue that the 8200 cal. BP event was part of a cooling period which began at c. 8600 cal. BP and lasted for several centuries. Further, it has been suggested that the climate in Fennoscandia was characterized by two or three colder episodes during a c. 400year period centered on $8000 \mathrm{cal}$. BP, rather than a single event (Ojala, et al. 2008; Zillen and Snowball 2009).

There are several pollen sediment cores from South Norway, but most have a low-resolution and/or are unpublished (Høeg, 2005). There are some exceptions, such as the highresolution pollen record from Lake Skogstjern, Bamble in Telemark County, obtained by the Institute of Pre- and Protohistoric Archaeology, University in Kiel, in cooperation with the Museum of Cultural History in Oslo (Wieckowska-Lüth et al., 2015, in prep.; cf. Persson, 2014; Solheim and Rødsrud, 2014). The pollen diagram indicates a changing forest landscape 
following the $8200 \mathrm{cal}$. BP cold event. The Corylus appear to decline as well as other warmdemanding wood taxa such as Ulmus, Quercus, Fraxinus and Tilia. At the same time, the low temperature adapted Pinus, Betula and Juniperus increase, demonstrating significant changes in the forest vegetation. These vegetation changes may be caused by the 8200 cal. BP event (Wieckowska-Lüth et al., 2015). Taking the large geographical variation in Norway in consideration, the extent of climate changes is likely to vary considerably from region to region. Even though the 8200 cal. BP event is evident in high-resolution paleoclimate records from Southern Norway, the majority of proxy data is obtained from the western coast and high alpine areas, and this makes it somewhat problematic to model the impact of Holocene climate changes in the Oslo fjord region.

\subsubsection{The Mesolithic coastal settlement of the Oslo fjord region}

The Stone Age settlement of southern Norway is closely connected to coastal communication and the availability and exploitation of marine resources (Bergsvik, 2001; Bjerck, 2009, 2016; Glørstad, 2013; Solheim and Persson, 2016). The poor organic preservation has eliminated almost all direct evidence for the exploitation of marine resources in Southeast Norway. Some sites have faunal remains exhibiting the exploitation of different marine resources as well as terrestrial resources (Jaksland, 2001; Hufthammer, 2006; Glørstad, 2010; Persson, 2014; Mansrud, 2014), and available data seems to suggest a diverse subsistence strategy during the Middle and Late Mesolithic (Glørstad, 2010; Solheim and Persson, 2016).

Figure 8: Top left: Mesolithic sites in the Larvik, Porsgrunn and Bamble municipalities, Southeast Norway, in today's landscape. The other maps show Mesolihtic sites in relation to raised shorelines. The maps illustrate the strong affinity to the ancient shorelines. Both inner and outer parts of the coastal areas were used during the Mesolithic.

Information about some of the fundamental adaptive traits of Stone Age societies in the region is first and foremoset available through site location (Figure 8). The majority of Mesolithic sites were situated close to the contemporary shoreline, often on islands in the outer archipelago.

Temporal trends in settlement strongly points to a close relation between Stone Age sites and changing shorelines during the Mesolithic. In Figure 9 we have plotted the radiocarbon 
dates from 33 Mesolithic sites from the western part of the region in relation to the local shoreline displacement curve. As illustrated by the figure, there is a strong correlation between the radiocarbon dates from Mesolithic sites and the shoreline displacement curve. The interpretation of this pattern is quite straightforward and it reflects a settlement pattern closely connected to a continuously shifting shoreline in the time period c. $10,100-6000$ cal. BP.

Figure 9: Radiocarbon dates from Stone Age sites are plotted the correct height above present sea level and in accordance to calibrated age BC. The calibration curves show a close relation to the shoreline displacement curve from Telemark/Vestfold. See Table 2 for individual dates. Figure by Steinar Solheim.

Table 2: The radiocarbon dates presented in figure 9.

Some C14-dates deviate from the general pattern and are worth commenting (see figure 9). The dated material (charcoal) is gathered from different archaeological features (cooking pits, hearths etc.) but in these cases there is no agreement between the radiocarbon dates and technological/typological dating and shoreline dating. All finds from these sites indicate that the activity phase is more than thousand years older than the radiocarbon dates. The seemingly erroneous dates are often interpreted as pollution by natural processes and later events (Nyland and Amundsen, 2012, pp. 188-189; Nyland, 2012b, pp. 162-163; Fossum, 2014, pp. 71-74; Jaksland, 2014, pp. 28-32). Such explanations seem plausible in many circumstances. The sites in the region mostly consist of podzol horizons under a thin layer of turf and it is documented that these can be severely affected by natural processes such as frost heaving and root activity (Boaz, 1998; Solheim and Olsen, 2013:221).

In some cases, the lacking correspondence between C14-dates and the technological, typological and shoreline age determinations are hard to explain by natural causes. One such site is Martineåsen, Larvik, where a hearth is dated to the Late Mesolithic, c. $8800-8400$ cal. BP, by four radiocarbon dates (Eymundsson and Mjærum, 2013). The site is shoreline and technologically/typologically dated to the Middle Mesolithic period with no lithic finds of Late Mesolithic character. The site is interpreted as having two activity phases: One during the Middle Mesolithic and one in the Late Mesolithic. This site does not correspond with the overall settlement pattern and most likely it shows a dynamical use of the landscape. The site is however situated near the contemporary shore $(100 \mathrm{~m})$ in the Late Mesolithic with an 
elevated location at the mouth of an ancient fjord system and might have been a monitoring site. We will however argue that settlement close the contemporary shoreline was by far most common and that the model in figure 9 displays the general pattern of shorebound settlement during the Mesolithic in the region.

Mesolithic settlement and the $8200 \mathrm{cal}$. BP event

The Late Mesolithic Nøstvet phase, starting at c. 8300 cal. BP, is interpreted as a period with increasing sedentism as sites from the period are larger and richer in finds than in earlier phases (Jaksland, 2001; Glørstad, 2010). The transition to the Late Mesolithic coincides with the $8200 \mathrm{cal}$. BP event but an analysis of shoreline-dated sites indicate that there is no detectable decrease in the relative number of sites following the climate event (Figure 10). This is in contrast to other regions in Europe where decrease and/or relocation of archaeological sites are detected (e.g. González-Sampériz, P., et al., 2009; Wicks and Mithen 2014).

The collapse of the Laurentide ice sheet triggering the 8200 cal. BP event caused a global sea level rise of 1.4 meters (Clarke et al., 2004; Törnqvist et al., 2004). Lotte Selsing (2010) argues that the sea level rise may have caused increased erosion and coastal sediment transport, resulting in an enriched marine productivity. This may have been a precondition for the the establishment of a stabile and semi-sedentary settlement along the Norwegian coast (Selsing, 2010, pp. 217-218).

A possible explanation to the observed pattern may thus be that the $8200 \mathrm{cal}$. BP event did not have a large impact on the coastal settlement in the region. Rick and Erlandson (2012) have suggested that foragers living in resource rich marine environments are less exposed to dramatic climatic events. As argued by Selsing (2010) changes in climate might not have had a negative effect on marine productivity, and possibly the 8200 cal. BP event did not affect the demography and settlement pattern of the Oslo fjord region to a noticeable degree.

A few aspects should, however, be mentioned here. The sites included in figure 10 are distributed in 500 yearlong intervals, which might be a too coarse resolution to identify possible changes in relation to rapid cold events. A more fine-grained resolution from the 
western part of the Oslo fjord region is thus presented in figure 11, with a resolution of 200400 years. Even here it is difficult to outline a significant change in settlement in relation to the 8200 cal. BP event, and a reduction in relative site numbers are seen prior to the event, at c. 9000-8800 cal. BP. This might be related to either representativeness, or possibly the decline in land upheaval during the Atlantic period, c. 8800-7800 cal. BP. A more stable shoreline have offered the possibility to use the same location for settlement for longer time spans, which might have triggered a more sedentary or place bound settlement.

Figure 10: Number of shoreline dated surveyed and excavated sites from the Oslo fjord region. The sites are dated according to 500 years intervals. No changes are documented in relation to the 8200 cal. BP event. Figure: Steinar Solheim.

Figure 11: Temporal distribution of surveyed sites ( $n=303$ sites) from Bamble, Larvik and Porsgrunn municipalities in Vestfold and Telemark counties, Southeast Norway. Figure: Steinar Solheim.

\subsubsection{Technological changes during the Middle Mesolithic-Late Mesolithic transition} Studies have shown that cultural aspects like lithic tool technology and settlement patterns are likely to change according to altered climate and resource availability (e.g. Crombé and Robinson 2016). Case studies document that the 8200 cal. BP cold event is linked to technological changes in various regions in Northern Europe (Riede, 2009; Riede et al., 2009; Holst, D., 2010; Robinson et al. 2013; Manninen, 2014).

In Southeast Norway the 8200 cal. BP cold event coincides with the Middle Mesolithic-Late Mesolithic transition (c. 8300 cal. BP). The Middle Mesolithic assemblages from coastal sites in Southeast Norway are first and foremost characterised by blades and microblades produced by pressure or indirect technique from conical and sub-conical cores with facetted platforms. Snapped/fragmented blades, scalene triangular microliths, barbed points, grinding slabs, ground-pecked adzes (also termed round butted adzes) made of local volcanic rocks are also frequent at sites. Flint is the most common raw material (Jaksland, 2001; Solheim and Damlien, 2013; Melvold and Persson, 2014; Damlien, 2014, 2016).

The Late Mesolithic assemblages are characterised by microblades produced by pressure technique from handle cores with smooth platforms, grinding slabs and Nøstvet adzes made of local volcanic rock. Flint is the dominating raw material (Mikkelsen, 1975; Glørstad, 2004; 
Eigeland, 2015). The technological transition between the Middle and the Late Mesolithic has been described as a gradual, continuous process where Middle Mesolithic elements are slowly being replaced by new ones (Glørstad, 2004).

Based on technological analyses from seven Mesolithic sites from the eastern part of Southeast Norway, Eigeland (2015) argues that the Middle and Late Mesolithic blade technologies are two very different technological concepts, and that there is no gradual development between the concepts. The Middle Mesolithic pressure blade concept is characterized by a gradual reduction of the core by detachment of blades of different dimensions. The striking platform is formed and rejuvenated by repeated detachments of core tablets and deliberate hinged rejuvenation flakes. Blade width varies, and there is no indication of separate macro- and microblade production. Rather, there is a gradual reduction of the core from the widest and longest to the narrowest and shortest blades. Macroblades are produced by indirect technique whereas blades and microblades are produced by pressure technique (Damlien, 2014, 2016; Eigeland, 2015; cf. Sørensen et al. 2013). Unlike the conical core concept, the Late Mesolithic handle core microblade production results in a standardized blank size. The handle core usually has an oblong shape and a flat, smooth platform. The striking platform is rarely rejuvenated, and the core is reduced lengthwise (Eigeland, 2015).

The Middle Mesolithic blade concept results in a variety of blanks sizes that can be modified to a wide range of tools. Furthermore, many blades/microblades are retouched or deliberately snapped. Due to their small and standardized dimensions, the Late Mesolithic microblades have a more limited usage than the Middle Mesolithic blades. This applies even if they were used as inserts in different composite tools (Eigeland, 2015, p. 154). The Late Mesolithic microblades are rarely modified by retouch. Eigeland further argues that the Middle and Late Mesolithic adze technologies are different. The Middle Mesolithic groundpecked adze is shaped with bifacial technique, pecked and partially grinded while the Late Mesolithic Nøstvet adze, on the other hand, is shaped by detaching flakes from an oblong, flat platform, giving the adze a triangular cross section. Only the edge of the adze is modified by grinding. These distinct breaks in both blade and adze technologies suggest that they represent two different technological traditions (Eigeland, 2015, p. 382). 
As lithic technology can be seen as cultural knowledge transmitted between individuals within a group or a tradition (Sørensen, 2006; Damlien, 2016), changes in technology can imply that demographic transformations were taking place in the Oslo fjord area at the Middle Mesolithic-Late Mesolithic transition. The question is if this is related to changes in climate seen in Northern Europe in general. Archaeological data from recent excavations on the western side of the Oslo fjord do however indicate that the Middle Mesolithic blade concept and axe technology is prevailing during the first half of the Late Mesolithic (Melvold and Persson, 2014; Reitan, 2016). The timing and mechanisms behind the technological changes around the Middle Mesolithic-Late Mesolithic transition, and the possible connection to the 8200 cal. BP cold event, are not yet explored and further studies are needed. Furthermore, it is urgent to analyse the technological and typological changes in light of new radiocarbon data, and investigate how this relates to the 8200 cal. BP event.

A parallel situation where climate and technological change coincide can be seen during the final stages of the Preboreal period. By analysing lithic blade assemblages from 28 settlement sites dated to c. 11,500-9500 cal. BP, Hege Damlien (2016a, 2016b) has discovered profound changes in the technological organization in the late Preboreal, $\mathrm{c}$. 10,400 cal. BP, with the introduction of the conical core pressure blade technology. This roughly correspond to the 10,300 cal. BP cold event, but Damlien argues that the changes are not primarily driven by environmental factors, but rather regulated by major social changes (Damlien, 2016b; see also Tallavaara et al., 2014). Damlien's research and the preliminary investigation presented above demonstrate the potential of the archaeological record from the Oslo fjord region to study human-environment relations. By comparing the archaeological record with high-resolution paleoenvironmental data it is possible to explore to what extent a changing environment affected hunter-gatherers occupying the Oslo fjord region throughout the Mesolithic. An important feature in both cases is that the coastal settlement seems to not be affected.

\subsection{Conclusions and future perspectives}

The cases underline several important points concerning human-environment relations: 
1) Climatic deteriorations may have had severe negative impact on terrestrial environments and resources. In these northern, coastal environments, however, the declining temperatures may have been less noticeable, or in fact have improved the living conditions for a range of marine species

2) Changes in lithic technology and settlement patterns are detected within the Mesolithic periods - a time span with climatic alterations and shifts. A direct correlation between abrupt climatic alterations and cultural changes are, however, yet to be proved. What we rather see is:

a. Gradual changes in the archaeological record that may be related to gradual stabilization in the climate, environment and resource base.

b. Profund changes in technology that perhaps was not driven by environmental factors at all.

c. Marine and coastal settlement does not seem to be affected by either the PBO or the 8200 cal. BP event.

3) The Mesolithic populations had resilient adaptive strategies that were projected into different landscapes and maintained through environmental fluctuations

However, the cases also reveal the need for better palaeo-environmental data, and there may be potential for studying these matters more closely in the future: The vast record of Mesolithic sites and artefacts in Norway, together with the steadily increasing highresolution palaeo-environmental data, has the potential to highlight many issues about human-environment relations, and contribute to the understanding of early marine foragers of Northwest-Europe.

There is a long tradition for reconstructing past environments and climate in Norway. Fluctuations in sea-levels and ice fronts have been recurrent topics throughout the archaeological history of research, and we now have quite comprehensive knowledge about these processes. Less is known about vegetation and fauna. Here, we largely have to rely on climatic proxy data in order to reconstruct the resource basis in this early phase of human occupation. The use of palaeo-environmental DNA (ancient DNA (aDNA)) originating from disseminated genetic material within palaeo-environmental samples) to reconstruct past environments is an emerging area of archaeological research (see Rawlence et al., 2014 for a 
review). Good palaeo-environmental DNA-samples are able to detect genetic traces of animals and plants that were physically present on the site. Provided undisturbed contexts and good sampling and analysis methods, this may be a possible avenue in Norwegian Stone Age research.

Breivik $(2014,2016)$ has made an effort is made to characterize the oceanic environment, with emphasis on productive habitats and temporal and spatial variations in the marine conditions in the Preboreal period. There are many possibilities to expand on this issue: Analyses of sediment cores may serve as the basis for models about meltwater discharge and sea ice. This can take us longer on the way of characterizing fjord environments and the extension of firm ice-cover and ice floes. Modellings of currents, wave action and tidal amplitudes are other factors can bring detail to our understanding of coastal environments in the Early Mesolithic.

Zooming in on smaller regions should also be interesting in this regard. The large amount of archaeological sites recorded and the increasing number of extensive excavations has left us with a very good foundation to conclude upon. Yet there is still need for more surveys and excavations in the mountain and especially in the fjord zone. Although the settlements in these zones seem, for some time periods, to be part of a mobility pattern that was based on the coast, questions could be asked about the relation between these sites and the role they play within this system: Are they hunting camps, intermediate stations or residential camps similar to those we find in the outer coastal areas (Breivik and Callanan, 2016)? More detailed studies on the intra-site matters on mountain and coastal sites may reveal additional interesting similarities and differences, giving more clues as to how these sites relate to each other and how the early inhabitants approached the landscapes. Tool distribution patterns and projectile morphology may be interesting in this regard. The investigation of Early Mesolithic sites and artefacts in central Norway has given a large record of tools and features ready to be studied in detail (Breivik and Bjerck, in press). We have also recorded numerous sites that have been used for a longer timespan or during later periods. This may be an interesting site group to analyze in relation to natural surroundings and intra-site similarities and differences. 
The substantial growth of archaeological data from the Mesolithic in Southeast Norway during the last 15 years covers sites from the Early Mesolithic to the Neolithic. In combination with the continuous land uplift, this provides high-resolution data well suited for studying breaks and continuity in lithic technology and settlement during the Mesolithic. A cautious estimate of 3000-4000 known Stone Age sites in the region provides excellent data for analyzing potential changes in human adaptation in relation to climatic events. There is a so far a little explored potential in the archaeological record for studies of the relation human-environment. In order to scrutinize the relation between climatic events, e.g. the 8200 cal. BP event and technology and settlement, there is a need for more highresolution proxy data on temperature and environmental changes. Identification of climatic events, such as the 10,300 or 8200 cal. BP event, that can easily be missed because of lower time resolution in the proxy records (e.g., Antonsson and Seppä, 2007, p. 407; Erbs-Hansen et al., 2011, p. 677), should be a future focus of investigation. Targeted analyses of suitable lakes and bogs in areas with rich archaeological data should be a priority.

\section{Acknowledgements}

We would like to thank the leaders of the INQUA HaBCom 1404 project, Erick Robinson and Felix Riede for inviting us into the network and for giving us the opportunity to present our projects for fellow researchers. Thanks also to the other members of the group, for fruitful discussions on cultural and palaeoenvironmental changes in Late Glacial to Middle Holocene Europe.

Heidi M. Breivik's PhD project was funded by The NTNU University Museum, Department of Archaeology and Cultural History. Guro Fossum's PhD project is funded by the Museum of Cultural History, University of Oslo.

\section{References}

Aaris-Sørensen, K., 2009. Diversity and dynamics of the mammalian fauna in Denmark throughout the last glacial-interglacial cycle, 115-0 kyr BP. Fossils and Strata 57, 1-60.

Alley, R.B., Mayewski, P.A., Sowers, T., Stuiver, M., Taylor, K.C., Clark, P.U., 1997. Holocene climatic instability: A prominent, widespread event 8200 yr ago. Geology 25, 483-486. 
Alley, R.B., Ágústsdóttir, A.M., 2005. The 8k event: cause and consequences of a major Holocene abrupt climate change. Quaternary Science Reviews 24, 1123-1149.

Antonsson, K., Seppä, H., 2007. Holocene temperatures in Bohuslän, southwest Sweden: a quantitative reconstruction from fossil pollen data. Boreas 36, 400-410.

Anundsen, K., 1985. Changes in shore-level and ice-front position in Late Weichsel and Holocene, southern Norway. Norwegian Journal of Geography 39(4), 204-225.

Barber D.C., Dyke, A., Hillaire-Marcel, C., Jennings, A.E., Andrews, J.T., Kerwin, M.W., Bilodeau, G., McNeely, R., Southon, J., Morehead, M.D., Gagnon, J.M., 1999. Forcing of the cold event of 8,200 years ago by catastrophic drainage of Laurentide lakes. Nature $400,344-$ 348.

Bergsvik, K.A., 2001. Sedentary and mobile hunter-fishers in Stone Age Western Norway. Arctic Anthropology 38(1), 2-26.

Bergstrøm, B., 1999. Glacial geology, deglaciation chronology and sea-level changes in the southern Telemark and Vestfold counties, southeastern Norway. NGU Bulletin 435, 3-42.

Birks, H.H., Kristensen, D.K., Dokken, T.M., Andersson, C., 2005. Exploratory comparisons of quantitative temperature estimates over the last deglaciation in Norway and the Norwegian Sea. Geophysical Monograph Series 158, 341-355.

Birks, H. H., Gelorini, V., Robinson, E., Hoek, W. C. 2015. Impacts of palaeoclimate change 60 000-8000 years ago on humans and their environments: integrating palaeoenvironmental and archaeological data. Quaternary International 378: 4-13.

Bjerck, H.B., 1983. Kronologisk og geografisk fordeling av mesolitiske element i Vest- og Midt-Norge. Unpublished thesis (Mag. Art.), University of Bergen, Norway.

Bjerck, H.B., 2008. Norwegian Mesolithic Trends: A review. In: Bailey, G.N., Spikins, P., (Eds.), Mesolithic Europe. Cambridge University Press, Cambridge, 60-106.

Bjerck, H.B., 2009. Colonizing seascapes: Comparative perspectives on the development of maritime relations in Scandinavia and Patagonia. Arctic Anthropology 46(1-2), 118-131.

Bjerck, H.B., 2016. Settlements and Seafaring: Reflections on the Integration of Boats and Settlements Among Marine Foragers in Early Mesolithic Norway and the Yámana of Tierra del Fuego. The Journal of Island and Coastal Archaeology, published online. DOI: 10.1080/15564894.2016.1190425

Bjerck, H.B., (ed.), Åstveit, L. I., Gundersen, J., Meling, T., Jørgensen, G., Normann, S., 2008. NTNU Vitenskapsmuseets arkeologiske unders $\varnothing$ kelser Ormen Lange Nyhamna. Tapir Academic Press, Trondheim. 
Björck, S., Rundgren, M., Ingólfsson, Ó., Funder, S., 1997. The Preboreal oscillation around the Nordic Seas: Terrestrial and lacustrine responses. Journal of Quaternary Science 12(6), 455-465.

Boaz, J. 1998. Hunter-Gatherer Site Variability: Changing Patterns of Site Utilization in the Interior of Eastern Norway, Between 8000 and 2500 B.P. University of Oslo, Oslo.

Bondevik, S., Svendsen, J.I., Mangerud, J., 1998. Distinction between the Storegga tsunami and the Holocene marine transgression in coastal basin deposits of western Norway. Journal of Quaternary Science 13, 529-537.

Breivik, H.M., 2014. Palaeo-oceanographic development and human adaptive strategies in the Pleistocene-Holocene transition: A study from the Norwegian coast. The Holocene, 24(11), 1478-1490.

Breivik, H.M., 2016. Dynamic relations between humans and environment in the earliest settlement phase of Norway (9500-8000 cal BC). PhD Thesis, University of Trondheim, Norway.

Breivik, H.M., Callanan, M., 2016. Hunting High and Low: Postglacial Colonization Strategies in Central Norway between 9500 and 8000 cal BC. European Journal of Archaeology. Published online. DOI:10.1080/14619571.2016.1147315

Breivik, H.M., Ellingsen, E.G., 2014. "A discovery of quite exceptional proportions": Controversies in the wake of Anders Nummedal's discoveries from Norway's first inhabitants. The Bulletin of the History of Archaeology 24(9): 1-13.

Breivik, H.M., Bjerck, H.B., in press. Early Mesolithic central Norway: A review of research history, settlements, and tool tradition. In: Blankholm, H.P., (Ed.), The Early Economy and Settlement in Northern Europe: Pioneering, Resource Use, Coping with Change, Vol. 3. Equinox Publishing, Sheffield.

Burroughs, W.J., 2005. Climate change in prehistory. The end of the reign of chaos. Cambridge University Press, Cambridge.

Callanan, M., 2007. On the Edge: a survey of Early Mesolithic Tools from Central Norway. Unpublished MA Thesis. University of Trondheim.

Clarke, G.K.C., Leverington, D.W., Teller, J.T., Dyke, A.S., 2004: Paleohydraulics of the last outburst flood from the glacial lake Agassiz and the 8200 BP cold event. Quaternary Science Reviews 23, 389-407.

Crombé, P., Sergant, J., Robinson, E., De Reu, J., 2011. Hunter-gatherer responses to environmental change during the Pleistocene-Holocene transition in the southern North Sea basin: Final Palaeolithic-Final Mesolithic land use in northwest Belgium. Journal of Anthropological Archaeology 30, 454-471. 
Crombé, P., Robinson, E., 2016. Human resilience to Lateglacial climate and environmental change in the Scheldt basin (NW Belgium). Quaternary International. Published online. DOI.org/10.1016/j.quaint.2015.10.116

Dahl, S.O., Nesje, A., 1994. Holocene glacier fluctuations at Hardangerjøkulen, centralsouthern Norway: a high-resolution composite chronology from lacustrine and terrestrial deposits. The Holocene 4, 269-277.

Dahl, S.O., Nesje, A., 1996. A new approach to calculating Holocene winter precipitation by combining glacier equilibrium-line altitudes and pine-tree limits: a case study from Hardangerjøkulen, central southern Norway. The Holocene 6, 381-398.

Damlien, H., 2016a. Eastern pioneers in westernmost territories? Current perspectives on Mesolithic hunter-gatherer large-scale interaction and migration within Northern Eurasia. Quaternary International 419: 5-16. Published online, http://dx.doi.org/10.1016/j.quaint.2014.02.023.

Damlien, H., 2016b. Between Tradition and Adaption. Long-term trajectories of lithic tool making in South Norway during the postglacial colonization and its aftermath (c. 9500-7500 cal. BC). Thesis submitted in fulfillment of the requirements for degree of Philosophiae Doctor (PhD). Faculty of Social Sciences. Museum of Archaeology. University of Stavanger, Stavanger.

Eigeland, L.C., 2015. Maskinmennesket i steinalderen. Endring og kontinuitet i steinteknologi fram mot neolitiseringen av $\emptyset$ st-Norge. Unpublished PhD thesis, University of Oslo.

Erbs-Hansen, D.R., Knudsen, K.L., Gary, A.C., Jansen, E., Gyllencreutz, R., Scao, V., Lambeck, K., 2011. Late Younger Dryas and early Holocene paleoenvironments in the Skagerrak, eastern North Atlantic: a multi-proxy study. Boreas 44, 660-680.

Eymundsson, C.S.R., Mjærum, A., 2013. Rapport fra arkeologisk utgravning. Anvik, 4067/9, Larvik, Vestfold. Unpublished archaeological report. Museum of Cultural History, University of Oslo.

Fossum, G., 2014. Gunnarsrød 7. En mellommesolittisk lokalitet med flere opphold. In: Melvold, S., Persson, P., (Eds.), Vestfoldbaneprosjektet. Arkeologiske unders $\varnothing$ kelser i forbindelse med ny jernbane mellom Larvik og Porsgrunn. Tidlig- og mellommesolittiske lokaliteter fra Vestfold og Telemark. Bind 1. Portal forlag, Kristiansand, 178-201.

Fredén, C., 1975. Subfossil finds of Arctic whales and seals in Sweden. Sveriges Geologiska Undersökning, C710, Årsbok 69(2), 1-62.

Fuglestvedt, I., 1999. The Early Mesolithic site at Stunner, Southeast Norway: A discussion of Late Upper Palaeolithic/Early Mesolithic chronology and cultural relations in Scandinavia. In: Boaz, J., (Ed.), The Mesolithic of Central Scandinavia. Universitetets oldsaksamlings skrifter, ny rekke 22: 189-202. 
Fuglestvedt, I., 2005. Pionerbosetningens fenomenologi. Sørvest-Norge og Nord-Europa 10200/10000-9500 BP. Archaeological Museum, Stavanger.

Fuglestvedt, I., 2007. The Ahrensburgian Galta 3 site in SW Norway. Dating, technology and cultural affinity. Acta Archaeologica 78(2), 87-110.

Gjerpe, L. E., (Ed.)., 2008. E18-prosjektet Vestfold: kulturhistoriske, metodiske og administrative erfaringer. Museum of Cultural History, University of Oslo.

Glørstad, H. (ed.), 2004. Svinesundprosjektet. Oppsummering av Svinesundprosjektet. Bind 4. Museum of Cultural History, University of Oslo, Oslo.

Glørstad, H., 2010. The Structure and History of the Late Mesolithic Societies in the Oslo Fjord Area 6300-3800 BC. Bricoleur Press, Lindome.

Glørstad, H., 2013. Where are the Missing Boats? The Pioneer Settlement of Norway as Long-Term History. Norwegian Archaeological Review 46(1), 57- 80.

Glørstad, H., 2016. Deglaciation, sea-level change and the Holocene colonization of Norway. Geological Society, London, Special Publications, 411(1), 9-25. doi:

http://dx.doi.org/10.1144/SP411.7

Grøndahl, F.A., Hufthammer, A.K., Dahl, S.O., Rosvold, J., 2010. A preboreal elk (Alces alces L., 1758) antler from south-eastern Norway. Fauna norvegica 30, 9-12.

González-Sampériz, P., et al., 2009. Patterns of human occupation during the early Holocene in the Central Ebro Basin (NE Spain) in response to the 8.2 ka climatic event. Quaternary Research, 71(2), 121-132.

Hafsten, U., 1983. Shore-level changes in South Norway during the last 13,000 years, traced by biostratigraphical methods and radiometric datings. Norwegian Journal of Geography $37(2), 63-79$.

Hammarlund, D., Björck, S., Buchardt, B., Israelson, C., Thomsen, C. T., 2003. Rapid hydrological changes during the Holocene revealed by stable isotope records of lacustrine carbonates from Lake Igelsjön, southern Sweden, Quaternary Science Review 22, 353-370.

Henningsmoen, K. E., 1979. En karbon-datert strandforskyvningskurve fra søndre Vestfold. In: Nydal, R., Westin, S., Hafsten, U., Gulliksen, S., (Eds.), Fortiden i søkelyset. Trondheim, 239-247.

Hoek, W. Z., Robinson, E., Gelorini, V. 2015. Climate impact on ecosystem changes and human responses during the Last Glacial and Early Holocene: A contribution to the INTIMATE (INTegration of Ice-core, MArine and TErrestrial records) COST Action ES0907. Quaternary International 378: 1-3. 
Holst, D., 2010. Hazelnut economy of early Holocene hunter-gatherers: a case study from Mesolithic Duvensee, northern Germany. Journal of Archaeological Science, 37, 2871-2880.

Hufthammer, A.K., 2001. The Weichselian (c. 115,000-10,000 B.P.) vertebrate fauna of Norway. Bollettino Della Societa Paleontologica Italiana, 40(2), 201-208.

Hufthammer, A.K., 2006. The vertebrate fauna of eastern Norway - from the Ice Age to the Middle Ages. KHM skrifter 4, 191-202.

Huston, M.A., Wolverton, S., 2009. The global distribution of net primary production: Resolving the paradox. Ecological Monographs, 79(3), 343-377.

Høeg, H.I., 2005. Den pollenanalytiske metoden og lokaliteter hvor det er utført pollenanalytiske undersøkelser. In: Stene, K., Amundsen, T., Risbøl, O., Skare, K., (Eds.), Utmarkens grøde. Mellom registrering og utgravning i Gråfjellområdet, $\varnothing$ sterdalen. Museum of Cultural History, University of Oslo, Oslo, pp. 27-52.

Jaksland, L., 2001. Vinterbrolokalitetene - en kronologisk sekvens fra mellom- og senmesolitikum i Ås, Akershus. Museum of Cultural History, University of Oslo, Oslo.

Jaksland, L., (Ed.), 2012. E18 Brunlanesprosjektet Bind 2. Unders $\emptyset$ kte lokaliteter fra tidligmesolitikum. Varia 80. Museum of Cultural History, University of Oslo, Oslo.

Jaksland, L., 2014. Kulturhistorisk sammenstilling In: Jaksland, L. and Persson, P., (Eds.), E18 Brunlanesprosjektet Bind 1. Forutsetninger og kulturhistorisk sammenstilling. Varia 79. Museum of Cultural History, University of Oslo, Oslo, 11-62.

Jessen, C. A., Pedersen, K. B., Christensen, C., Olsen, J., Mortensen, M. F., Hansen, K. M., 2015. Early Maglemosian culture in the Preboreal landscape: Archaeology and vegetation from the earliest Mesolithic site in Denmark at Lundby Mose, Sjælland. Quaternary International 378: 73-87. Published online, http://dx.doi.org/10.1016/j.quaint.2014.03.056

Jonsson, L., 1995. Vertebrate fauna during the Mesolithic on the Swedish west coast. In: Fischer, A., (Ed.), Man and sea in the Mesolithic. Oxbow Books, Oxford, pp. 147-160.

Kindgren, H., 1996. Reindeer or seals? Some Late Palaeolithic sites in central Bohuslän. In: Larsson, L., (Ed.), The Earliest settlement of Scandinavia. Acta Archaeologica Lundensia, Series in 8, No 24: 191-205.

Koxvold, L., in prep. Langemyr. Arkeologisk utgravningsrapport. Unpublished archaeological report. Museum of Cultural History, University of Oslo.

Kutschera, M., 1999. Vestnorsk tidligmesolitikum i et nordvesteuropeisk perspektiv. In: Fuglestvedt, I., Gansum, T., Opedal, A., (Eds.), Et hus med mange rom. Vennebok til Bjørn Myhre på 60-årsdagen. Arkeologisk museum, Universitetet i Stavanger, Stavanger, pp. 43-52. 
Kutschera, M., Waraas, T.A., 2000. Steinalderlokaliteten på "Breiviksklubben" på BrattHelgaland i Karm øy kommune. In: Løken, T., (Ed.), Åsgard: natur- og kulturhistoriske unders $\varnothing$ kelser langs en gassrør-trasé i Karmøy og Tysvær, Rogaland. Arkeologisk museum, Universitetet i Stavanger, Stavanger, pp. 61-96.

Manninen, M.A., 2014. Culture, behaviour, and the 8200 cal BP cold event. Organisational change and culture-environment dynamics in the late Mesolithic Northern Fennoscandia. Monographs of the archaeological Society of Finland 4. PhD Thesis, University of Helsinki, Finland.

Mansrud, A., 2014. Mobil eller bofast? Erverv, landskap og mobilitet i mellommesolittiske kystsamfunn i Øst-Norge (8300-6300 f. Kr.). Norsk Maritimt Museums Årbok 2013, 67-108.

Melvold, S., Persson, P., (Eds.)., 2014. Vestfoldbaneprosjektet. Arkeologiske unders $\varnothing$ kelser i forbindelse med ny jernbane mellom Larvik og Porsgrunn. Tidlig- og mellommesolittiske lokaliteter fra Vestfold og Telemark. Bind 1. Portal forlag, Kristiansand.

Mikkelsen, E., 1975. Mesolithic in South-eastern Norway. Norwegian Archaeological Review, 8(1), 19-35.

Moen, A., 1999: National Atlas of Norway: Vegetation. Norwegian Mapping Authority, Hønefoss.

Moore, S.E., Huntington, H.P., 2008. Artic Marine Mammals and Climate Change: Impacts and Resilience. Ecological Applications, 18, 157-165. Published online, doi:10.1890/060571.1.

Møllenhus, K.R., 1977. Mesolitiske boplasser på Møre- og Trøndelagskysten. Det Kongelige Norske Videnskabers Selskab, Museet, Trondheim.

Nyland, A.J., 2012a. Lokaliseringsanalyse av tidligmesolittiske pionerboplasser. In: Glørstad, H., Kvalø, F., (Eds.), HAVVIND - Paleogeografi og arkeologi - Archaeological Report. Norwegian Maritime Museum, Museum of Cultural History, Oslo, pp. 70-96.

Nyland, A.J., 2012b. Pauler 2. Boplass fra tidligmesolitikum. In: Jaksland, L., (Ed.), E18 Brunlanesprosjektet. Bind III. Unders $\varnothing$ kte lokaliteter fra tidligmesolitikum og senere. Varia 81. Museum of Cultural History, University of Oslo, Oslo, 127-169.

Nyland, A.J., Amundsen, T., 2012. Bakke - boplass fra tidligmesolitikum, In: Jaksland, L., (Ed.), E18 Brunlanesprosjektet. Bind III. Undersøkte lokaliteter fra tidligmesolitikum og senere. Varia 81. Museum of Cultural History, University of Oslo, Oslo, 199-228.

Odgaard, U., 1993. C.nr. 38156, E18 - Rugtvedt, Bamble kommune, Telemark fylke. Unpublished archaeological report. Museum of Cultural History, University of Oslo. 
Ojala, A. E. K., et al., 2008. Characterizing changes in the sedimentary environment of a varved lake sediment record in southern central Finland around 8000 cal. yr BP. Journal of Quaternary Science 23(8), 765-775.

Olsen, A. B., 1992. Kotedalen - en boplass gjennom 5000 år. Bind I. Fangstbosetning og tidlig jordbruk i Vestnorsk steinalder, Nye funn og nye perspektiver. University of Bergen, Bergen.

Paus, A., 2010. Vegetation and environment of the Rødalen alpine area, Central Norway, with emphasis on the early Holocene. Vegetation History and Archaeobotany 19(1), 21-51.

Perez, S. I., Postillone, M. B., Rindel, D., Gobbo, D., Gonzalez, P. N., Bernal, V., 2016, Peopling time, spatial occupation and demography of Late Pleistocene-Holocene human population from Patagonia. Quaternary International. Published online, http://dx.doi.org/10.1016/j.quaint.2016.05.004.

Persson, P., 2014. Naturvetenskap. In: Melvold, S., Persson, P., (Eds.), Vestfoldbaneprosjektet. Arkeologiske unders $\varnothing$ kelser i forbindelse med ny jernbane mellom Larvik og Porsgrunn. Tidlig- og mellommesolittiske lokaliteter fra Vestfold og Telemark. Bind 1. Portal forlag, Kristiansand, 76-87.

Påsse, T., 2003. Strandlinjeförskjutning i norra Bohuslän under holocen. In: Persson, P., (Ed.), Strandlinjer och vegetationshistoria. Kvartärgeologiska undersökningar inom Kust till kust projektet, 1998-2002, pp. 33-88.

Rawlence, N.J., Lowe, D.J., Wood, J.R., Young, J.M., Churchman, G.J, Huang, Y., Cooper, A., 2014. Using palaeoenvironmental DNA to reconstruct past environments: progress and prospects. Journal of Quaternary Science 29(7), 610-626.

Reitan, G. and Persson, P., (Eds.) 2014. Vestfoldbaneprosjektet. Seinmesolittiske, neolittiske og yngre lokaliteter fra Telemark og Vestfold. Bind 2. Portal forlag, Kristiansand.

Reitan, G., 2016. Mesolittisk kronologi i Sørøst-Norge - et forslag til justering. Viking 79, 2351.

Rick, T., Erlandson, J.M., 2012. Kelp Forests, coastal migrations, and the Younger Dryas: Late Pleistocene and earliest Holocene Human Settlement, Subsistence, and Ecology on California's Channel Islands. In: Eren, M., (Ed.) Hunter-gatherer behavior. Human Response during the Younger Dryas. Routledge, California, 79-111.

Riede, F., 2009. Climate and demography in early prehistory: Using calibrated $14 \mathrm{C}$ dates as population proxies. Human Biology 81(2-3), 309-337.

Riede, F., Edinborough, K., Thomas, M., 2009. Tracking Mesolithic demography in time and space and its implications for explanations of cultural change. In: Crombé, P., Strydonck, M.V., Sergant, J., Bats, M., Boudin, M., (Eds.), Chronology and Evolution wirhin the Mesolithic of North-West Europe. Cambridge Scholars Press, Cambridge, 177-194. 
Risebrobakken, B., Moros, M., Ivanova, E.V., Chistyakova, N., Rosenberg, R., 2010. Climate and oceanographic variability in the SW Barents Sea during the Holocene. The Holocene 20(4), 609-621.

Robinson, E., Van Strydonck, M., Gelorini, V., Crombé, P., 2013. Radiocarbon chronology and the correlation of hunter-gatherer sociocultural change with abrupt palaeoclimate change: the Middle Mesolithic in the Rhine-Meuse-Scheldt area of northwest Europe. Journal of Archaeological Science, 40(1), 755-763.

Rohling, E.J., Pälike, H., 2005. Centennial-scale climate cooling with a sudden cold event around 8,200 years ago. Nature 434(7036), 975-979.

Rosvold, J., Breivik, H.M., in press. An Early Holocene bearded seal from the Trondheimsfjord: environmental and archaeological implications. In: Persson, P., Riede, F., Skar, B., Breivik, H.M., Jonsson, L. (Eds.), The Early Settlement of Northern Europe: An Ecological Approach. Equinox Publishing, Sheffield.

Selsing, L., 2010. Mennesker og natur i fjellet i Sør-Norge etter siste istid med hovedvekt på mesolitikum. AmS-Varia 51. Museum of Archaeology, Stavanger.

Seppä, H., Birks, H.J.B., Giesecke, T., Hammarlund, D., Alenius, T., Antonsson, K., Bjune, A.E., Heikkilä, M., Macdonald, G.M., Ojala, A.E.K., Telford, R.J., Veski., S., 2007. Spatial structure of the 8200 cal yr BP event in Northern Europe. Climate of the Past Discussions, European Geosciences Union 3(1), 165-195.

Seppä, H., Bjune, A. E., Telford, R. J., Birks, H. J. B., Veski. S., 2009. Nine thounsand years of temperature variability in Northern Europe. Climate of the Past 5, 523-535.

Solheim, S., (ed). 2017 (in prep). E18 Rugtvedt-Dørdal. Unders $\varnothing$ kelser av lokaliteter steinalder og jernalder i Bamble kommune, Telemark fylke. Portal forlag, Kristiansand

Solheim, S., Damlien, H., (Eds.), 2013. Bommestad-Sky. Undersøkelser av lokaliteter fra mellommesolitikum, Larvik kommune, Vestfold fylke. Portal forlag, Kristiansand.

Solheim, S., Olsen, D. E. F., 2013). Hovland 3 - Mellommesolittisk boplass med hyttetuft. In: Solheim, S., Damlien, H., (Eds.), E18 Bommestad-Sky. Undersøkelser av lokaliteter fra mellommesolitikum, Larvik kommune, Vestfold fylke. Portal forlag, 198 - 235

Solheim, S., Rødsrud, C.L., (Eds.), 2014. E18 Rugtvedt-Dørdal. Arkeologiske unders $\varnothing$ kelser i Bamble kommune, Telemark fylke. Årsrapport 2014. Museum of Cultural History, University of Oslo, Oslo.

Solheim, S., Persson, P., 2016. Marine adaptation in the Middle Mesolithic of South-Eastern Norway. In: Bjerck, H.B. Breivik, H.M., Fretheim, S.E., Piana, E.L., Skar, B., Tivoli, A.M., Zangrando, A.F.J., (Eds.), Marine Ventures. Archaeological Perspectives on Human-Sea Relations. Equinox Publishing, Sheffield, 255-270. 
Statham, P.J., Skidmore, M., Tranter, M., 2008. Inputs of glacially derived dissolved and colloidal iron to the coastal ocean and implications for primary productivity. Global Biogeochemical Cycles 22, GB3013.

Stroeven, A.P. et al., 2015. Deglaciation of Fennoscandia. Quaternary Science Reviews. http://dx.doi.org/10.1016/i.quascirev.2015.09.016

Svendsen, F., 2007. Lokaliteter og landskap i tidlig mesolittisk tid. En geografisk analyse fra Nordvest-Norge. Unpublished thesis (MA). University of Trondheim, Norway.

Svendsen, J. I. et al. 2004. Late Quaternary ice sheet history of northern Eurasia. Quaternary Science Reviews 23(11), 1229-1271.

Sørensen, M., 2006. Rethinking the lithic blade definition: towards a dynamic understanding. In: Apel, J., Knutsson, K., (Eds.), Skilled Production and Social Reproduction. Aspects of Traditional Stone-Tool Technologies, Proceedings from an International Symposium held in Uppsala August 20-24, 2003. Stone Studies No. 2. Societas Archaeologica Upsaliensis, Uppsala, pp. 277-299.

Sørensen, R. 1979. Late Weichselian deglaciation in the Oslofjord area, south Norway. Boreas 8(2), 241-246.

Sørensen, R., Høeg, H.I., Henningsmoen, K.E., Skog, G., Labowsky, S.F., Stabel, B., 2014. Utviklingen av det senglasiale og tidlig preboreale landskapet og vegetasjon omkring steinalderboplassene ved Pauler, Larvik kommune, Vestfold. In: Jaksland, L., Persson, P., (Eds.), E18 Brunlanesprosjektet Bind 1. Forutsetninger og kulturhistorisk sammenstilling. Varia 79. Museum of Cultural History, University of Oslo, Oslo, 171-293.

Tallavaara, M., Seppä, H., 2011. Did the mid-Holocene environmental changes cause the boom and bust of hunter-gatherer population size in eastern Fennoscandia? The Holocene, 22(2), 215-225.

Tallavaara et al. 2014. The mere possibility of biases does not invalidate archaeological population proxies-response to Teemu Mökkönen. Fennoscandia Archaeologica 31, 135140.

Törnqvist, T.E., Bick, S.J., González, J.L., van der Borg, K., de Jong, A.F.M., 2004. Tracking the sea-level signature of the 8.2 ka cooling event: New constraints from the Mississippi Delta, Geophysical Research Letters 31, L23309. Published online, doi:10.1029/2004GL021429.

Velle, G., Brooks, S.J., Birks, H.J.B., Willassen, E., 2005. Chironomids as a tool for inferring Holocene climate: an assessment based on six sites in southern Scandinavia. Quaternary Science Reviews 24, 1429-1462.

Walker, M.J.C., Berkelhammer, M., Björck, S., Cwynar, L.C., Fisher, D.A., Long, A.J., Lowe, J.J., Newnham, R.M., Rasmussen, S.O., Weiss, H., 2012. Formal subdivision of the Holocene Series/Epoch: a Discussion Paper by a Working Group of INTIMATE (Integration of ice-core, 
marine and terrestrial records) and the Subcommission on Quaternary Stratigraphy (International Commission on Stratigraphy). Journal of Quaternary Science 27(7), 649-659.

Waraas, T.A., 2001. Vestlandet i tidleg Preboreal tid. Fosna, Ahrensburg eller vestnorsk tidligmesolitikum? Unpublished thesis (MA). University of Bergen, Norway.

Wicks, K., Mithen, S., 2014. The impact of the abrupt 8.2 ka cold event on the Mesolithic population of western Scotland: a Bayesian chronological analysis using 'activity events' as a population proxy. Journal of Archaeological Science, 45, 240-269.

Wieckowska-Lüth, M., Dörfler, W., Kirleis, W., 2015. A more than 10500 years, high resolution record of vegetation history and -dynamics, human impact and erosion history from Lake Skogtjern, Southern Norway. Final report. Institute of Pre- and Protohistoric Archaeology Christian-Albrechts University Kiel, Germany.

Wieckowska-Lüth, M., Dörfler, W., Kirleis, W., in prep. Holocene history of landscape development in the catchment of Lake Skogstjern, southeastern Norway, based on a highresolution multi-proxy record".

Zillen, L., Snowball, I., 2009. Complexity of the 8 ka climate event in Sweden recorded by varved lake sediments. Boreas 38(3), 493-503.

Østmo, E. 1976. Torsrød. En senmesolittisk kystboplass I Vestfold. Universitetets Oldsakssamling Årbok 1972-1974, 41-52. 